\title{
Purification and characterization of the first recombinant bird pancreatic lipase expressed in Pichia pastoris: The turkey
}

\author{
Madiha Bou Ali ${ }^{\dagger}$, Yassine Ben Ali ${ }^{\dagger}$, Aida Karray, Ahmed Fendri, Youssef Gargouri
}

\begin{abstract}
Background: The turkey pancreatic lipase (TPL) was purified from delipidated pancreases. Some biochemical properties and kinetic studies were determined using emulsified system and monomolecular film techniques. Those studies have shown that despite the accumulation of free fatty acids at the olive oil/water interface, TPL continues to hydrolyse efficiently the olive oil and the $\mathrm{TC}_{4}$ in the absence of colipase and bile salts, contrary to most classical digestive lipases which denaturate rapidly under the same conditions. The aim of the present study was to express TPL in the methylotrophic yeast Pichia pastoris in order to get a large amount of this enzyme exhibiting interesting biochemical properties, to purify and characterize the recombinant enzyme.

Results: The recombinant TPL was secreted into the culture medium and the expression level reached about $15 \mathrm{mg} / \mathrm{l}$ after 4 days of culture. Using Q-PCR, the number of expression cassette integrated on Pichia genomic DNA was estimated to 5 . The purified rTPL, with molecular mass of $50 \mathrm{kDa}$, has a specific activity of $5300 \mathrm{U} / \mathrm{mg}$ on emulsified olive oil and $9500 \mathrm{U} / \mathrm{mg}$ on tributyrin. The optimal temperature and $\mathrm{pH}$ of $\mathrm{rTPL}$ were $37^{\circ} \mathrm{C}$ and $\mathrm{pH} 8.5$. The stability, reaction kinetics and effects of calcium ions and bile salts were also determined.

Conclusions: Our results show that the expressed TPL have the same properties as the native TPL previously purified. This result allows us the use of the recombinant enzyme to investigate the TPL structure-function relationships.
\end{abstract}

\section{Background}

Lipases are defined as triacylglycerol acylhydrolases (E.C.3.1.1.3) that catalyze the hydrolysis of fats and oils at the oil-water interface to glycerol and free fatty acids. Although lipases belong to many different protein families without sequence similarity, there is a much greater conservation in the secondary and tertiary structures of lipases [1].

Over the last years, a better understanding of pancreatic lipases structure-function relationships has been reached with the resolution of several three-dimensional structures $[2,3]$. The resolution of the three-dimensional structure of human pancreatic lipase (HPL) [2] has shown that the single polypeptide chain (449 amino acids) is fold into two domains: a large $\mathrm{N}$-terminal

\footnotetext{
* Correspondence: ytgargouri@yahoo.fr

† Contributed equally

Laboratoire de Biochimie et de Génie Enzymatique des Lipases, ENIS route de Soukra, BP1173, University of Sfax, 3038 Sfax, Tunisia
}

domain (residue 1-335) which shows a typical $\alpha / \beta$ hydrolase fold and a small $\mathrm{C}$-terminal domain (residue 336-449) which is of $\beta$ sandwich type [4].

The N-terminal domain contains the active site, which involves a catalytic triad analogous to that present in serine proteases. A surface loop (Cys 237-Cys 261), the so-called lid or flap, prevents the access of the substrate to the active site in its closed conformation. HPL requires a small protein cofactor, colipase, for the enzyme to be able to bind, in the presence of bile salt, to the triacylglycerol/water interface. Colipase binds to the C-terminal domain of HPL and exposes the hydrophobic tips of its fingers at the opposite side of its lipase-binding site [5]. The open lid and the extremities of the colipase fingers, as well as the $\beta 9$ loop, form an impressive continuous hydrophobic plateau extending over more than $50 \mathrm{~A}^{\circ 2}$, which might be to interact strongly with a lipid/water interface [6].

\section{C) Biomed Central}


The turkey pancreatic lipase (TPL) was purified from delipidated pancreases. This avian pancreatic lipase contains 450 amino acids and presents an experimental mass of $49665.31 \mathrm{Da}$ [7]. Some biochemical properties and kinetic studies were determined using emulsified system and monomolecular film techniques [8,9]. Those studies have shown that despite the accumulation of free fatty acids at the olive oil/water interface, TPL continues to hydrolyse efficiently the olive oil and the $\mathrm{TC}_{4}$ in the absence of colipase and bile salts, contrary to most classical digestive lipases which denaturate rapidly under the same conditions [10,11].

Fendri et al. have determined the critical surface pressure (Пc) of TPL corresponding to the interaction power with Egg-PC monolayers. They found that TPL presents a higher $\Pi c\left(\Pi c=29 \mathrm{mNm}^{-1}\right)$ [9] in comparison with HPL $\left(\Pi c=18 \mathrm{mNm}^{-1}\right)$ [11]. This result has been explained by the fact that the hydrophobic surface of TPL is higher by $166 \mathrm{~A}^{\circ 2}$, as compared to that of HPL. So, hydrophobic interactions between the lipase and the substrate would be more efficient in the case of TPL than in that of HPL.

The cleavage of TPL by chymotrypsin has generated three major fragments of about 35,14 and $10 \mathrm{kDa}$. The $\mathrm{N}$-terminal of the $35 \mathrm{kDa}$ fragment was the same as the native TPL [12]. So this truncated TPL form would correspond to the TPL $\mathrm{N}$-terminal domain which was active on tributyrin emulsion in the absence of colipase and in the presence of a low concentration of bile salts. Others attempts to produce an active $\mathrm{N}$-terminal pancreatic lipase domain by limited proteolysis were failures with the HPL, PPL and OPL [12-14], except with the horse pancreatic lipase giving to a large $\mathrm{N}$-terminal fragment $(45 \mathrm{kDa})$ which retained the lipase activity.

To investigate the structure-fonction relationships of the TPL, a high expression level system of TPL is required. The methylotrophic yeast Pichia pastoris is a host system which has been widely used at both academic and industrial laboratories in the production of a variety of heterologous proteins [15].

Pichia pastoris has a strong preference for respiratory growth, consequently it doesn't produce significant amount of toxic ethanol as compared to many species of the genus saccharomyces [16] and may grow to very high cell densities on inexpensive media.

Like other eukaryotic expression systems, Pichia pastoris presents many advantages, such as proteolytic processing, folding, disulphide bonds formation and glycosylation, as well as several other post-translational modifications.

This expression system gives efficient recombinant protein secretion level which, combined with the very low endogenous protein secretion level, is a great advantage for the purification of the recombinant protein secreted into the culture medium [15]. Pichia pastoris system based on the constitutive promoter glyceraldehyde-3-phosphate dehydrogenase gene (GAP) have recently became available [17]. The GAP promoter for the heterologous expression of genes giving products which are not toxic to Pichia pastoris, or when the use of methanol, a highly toxic solvent, has to be ruled out.

In this paper, we report the expression of the TPL gene in Pichia pastoris, the recombinant enzyme was purified and its properties are compared to the native one.

\section{Results and discussion}

\section{Generation of recombinant Pichia clones expressing TPL}

The TPL gene, containing two EcoRI sites upstream of its first codon and downstream of its Stop codon, was digested by the EcoRI restriction enzyme and inserted into the pGAPZ $\alpha$ A vector previously digested by EcoRI. The recombinant vector was then linearized by the BspHI restriction enzyme and the GAP promoter-driven constitutive expression of TPL was achieved by integrating the linearised pGAPZ $\alpha$ A-TPL plasmid into the X33 wild type P-Pastoris genome at the GAP locus. P.pastoris tranformants generated by electroporation with the recombinant vector ( $\mathrm{pGAPZ} \alpha \mathrm{A}-\mathrm{TPL}$ ) were selected on YPDS plates containing Zeocin and incubated at $30^{\circ} \mathrm{C}$ for 3 days. Six randomly picked Zeocin resistant positives clones on the solid selective medium were selected and the presence of TPL insert in the Zeo-resistant transformants was checked by PCR.

\section{Lipase producing level of selected clones}

To confirm the integration of the TPL gene into the P.pastoris genome, we have performed a PCR reaction using as template the genomic DNA of the selected clones. We found that the $\mathrm{C} 1, \mathrm{C} 2, \mathrm{C} 3, \mathrm{C} 4, \mathrm{C} 5$ and C6 clones, show an amplification of a 1900 pb fragment corresponding to the TPL gene $(1353 \mathrm{pb})$ plus a portion of the vector $(540 \mathrm{pb})$ which is amplified even in the absence of integration (Figure 1). This result suggests the integration of the TPL DNA into the Pichia X33 genome (Figure 1). Positive clones were then cultivated in Erlenmeyer's flasks to identify which clone has the highest lipase production level. Samples were collected during 6 days and assayed for the lipase activity (Figure 2A).

Figure 2A describe the variation of rTPL activity in the culture medium as function of culture days. It shows that the C5 and C6 clones exhibit the highest activity levels which reach about $100 \mathrm{U} / \mathrm{ml}$ after 6 days of culture. C5 clone was chosen to continue this study.

It is well known that protease degradation is the main problem of protein expressed in heterologous system [18]. One solution to avoid this degradation is to reduce the culture period. In this purpose we have chosen to start the cell culture with an OD of 1 , which 


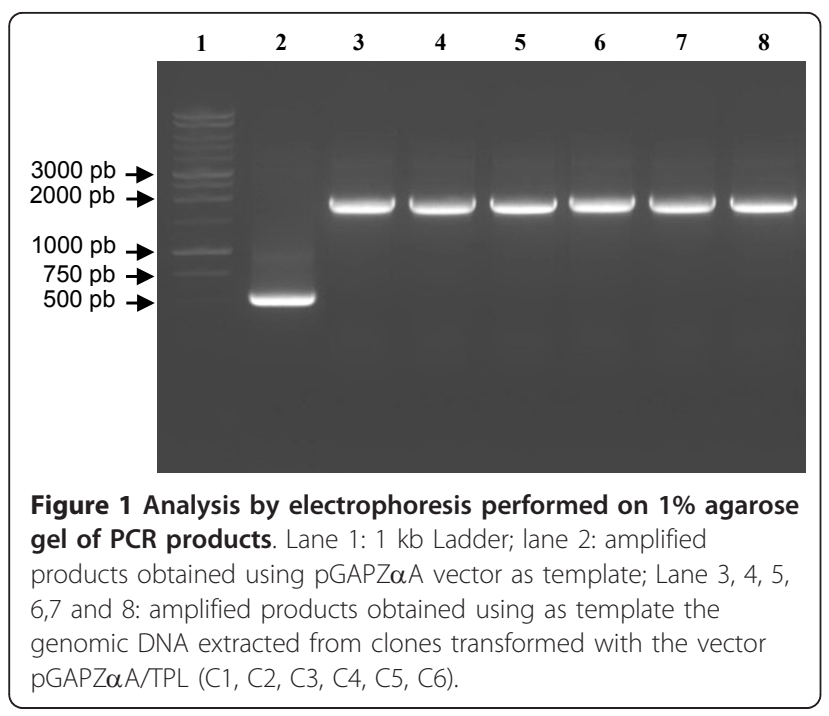

allowed a shift of the production period from 6 to 4 days (Figure 2B).

The secretion of the recombinant protein was detected $24 \mathrm{~h}$ after the culture was initiated, and a maximum activity level of $75 \mathrm{U} / \mathrm{ml}$ was reached after 4 days. Starting the $5^{\text {th }}$ day, a slight decrease in the rTPL activity was observed suggesting a probable proteolytic degradation of the expressed protein.

\section{Analysis of TPL CDNA copies number in selected recombinant strains by Q-PCR}

Genomic DNA extracted from the six selected clones were analyzed by Q-PCR to estimate the TPL cDNA copies number. As shown in figure 3A, C1, C4, C5 and C6 clones have approximately the same $\mathrm{Ct}=28$, reflecting an identical copies number of TPL cDNA in their genomic DNA. The $\mathrm{C} 2$ and $\mathrm{C} 3$ clones have a Ct value of 31 .

Based on the standard curve done with 10 fold serial dilution of plasmid DNA (pGAPZ $\alpha$ A/TPL), the number of expression cassette integrated was estimated to five copies for $\mathrm{C} 1, \mathrm{C} 4, \mathrm{C} 5$ and $\mathrm{C} 6$ and four copies for $\mathrm{C} 2$ and $\mathrm{C} 3$ clones (Figure 3B). These results are in agreement with the difference in the activity levels of these clones (Figure 2A). In fact C2 and C3 exhibit the lowest lipase activity level compared to the other clones.

\section{Production of rTPL in P.pastoris}

After 4 days of yeast growth, the corresponding amount of recombinant TPL reached about $15 \mathrm{mg} / \mathrm{l}$ of culture medium. This production rate can be middling in comparison with other production levels of various esterases and lipases expressed in P.pastoris. For comparison, the production rate of the Carp acetylcholinesterase is about $40 \mu \mathrm{g} / \mathrm{l}$ of culture medium after 10 days of methanol induction [19]. The human pancreatic lipase-related

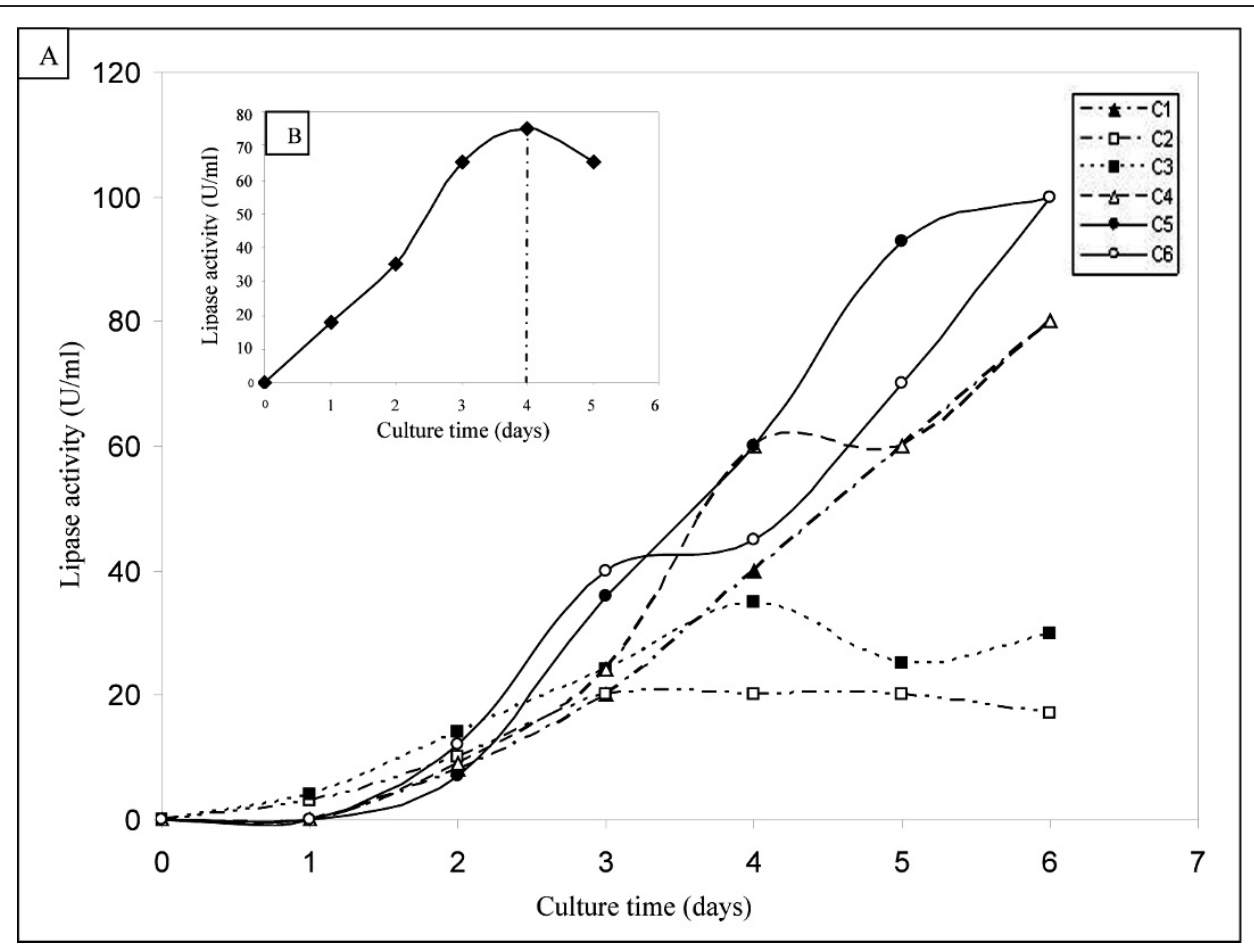

Figure 2 Time-course of rTPL expression. (A) The six isolated clones of recombinant P.pastoris. (B, insert) The time-course of the rTPL expression by the selected clone (C5). 

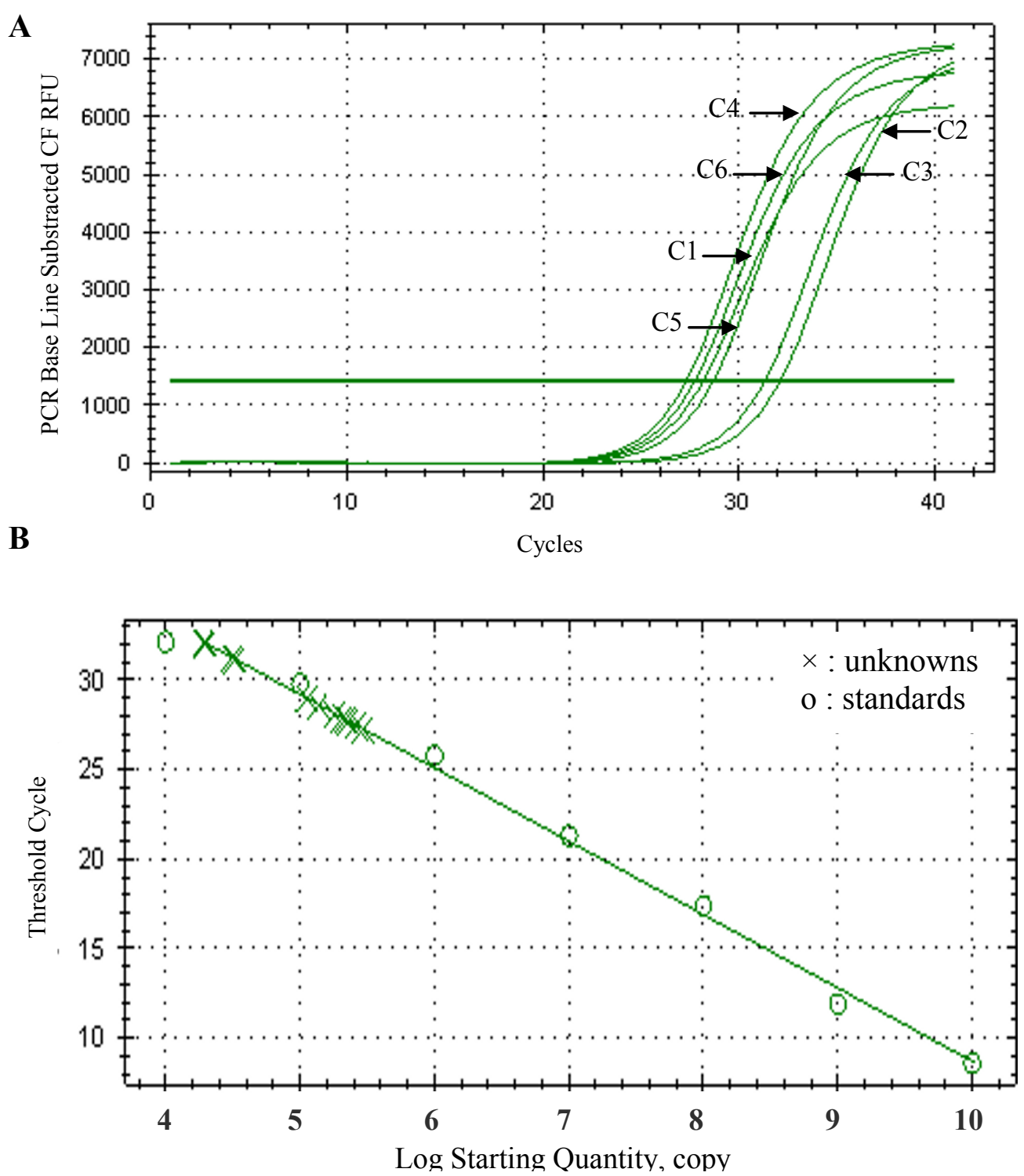

Figure 3 Q-PCR analysis of the TPL CDNA copies number in the genomic DNA of C1, C2, C3, C4, C5 and C6 clones. Correlation coefficient: 0.993; Slope: -4.100; PCR Efficiency: 75.3\%.

protein 2 has a productivity of $40 \mathrm{mg} / \mathrm{l}$ under the control of the AOX1 promoter and about $4 \mathrm{mg} / \mathrm{l}$ under the control of the constitutive GAP promoter [20]. This difference could not be caused by the constitutive promoter efficiency because this promoter has been successfully used to secrete a high level of mature rHPLRP1 (100-120 mg/l) [21]. Recombinant human Bile salt-simulated lipase has a production amount of 0.8-1 g/l [22].

Some studies described the expression of fungical lipases in P.pastoris, the Lip2 lipase of Yarrowia lipolytica was successfully expressed in P.pastoris with an expression level of around $0.63 \mathrm{~g} / \mathrm{l}$ [23]. C.rugosa Lip4 lipase [24] and Mutant Nippostrogglus brasiliensis
Acetylcholinesterase [25] were expressed with a production level of 0.1 and $2 \mathrm{~g} / \mathrm{l}$ respectively.

\section{Purification of rTPL expressed in P.pastoris}

After 4 days of time course fermentation, $500 \mathrm{ml}$ of culture broth were centrifuged at $9500 \mathrm{rpm}$ for $30 \mathrm{~min}$ to discard the yeast cells.

\section{Ammonium sulfate precipitation}

The supernatant was brought to $60 \%$ saturation with solid ammonium sulfate under stirring conditions and maintained for $60 \mathrm{~min}$ at $4{ }^{\circ} \mathrm{C}$. After centrifugation (30 $\mathrm{min}$ at $9500 \mathrm{rpm}$ ), the precipitate was resuspended 
in $5 \mathrm{ml}$ of buffer A (250 mM Tris- $\mathrm{HCl}, \mathrm{pH} 8.2,250 \mathrm{mM}$ $\mathrm{NaCl}, 20 \mathrm{mM}$ Benzamidine). Insoluble material was removed by centrifugation for $10 \mathrm{~min}$ at $9500 \mathrm{rpm}$.

\section{Anion exchange chromatography on DEAE -Cellulose}

The supernatant was diluted 10x with distilled water and loaded on a DEAE-Cellulose anion exchanger equilibrate in buffer B $(25 \mathrm{mM}$ Tris- $\mathrm{HCl} \mathrm{pH} 8.2,25 \mathrm{mM} \mathrm{NaCl}$, $2 \mathrm{mM}$ Benzamindine). Under these conditions, the rTPL doesn't absorb on the anionic support and was then eluted during the washing step using the same buffer.

\section{Filtration on Sephacryl S200}

Active fractions were pooled and concentrated using an Amicon Ultra-15 (molecular weight cutoff of $10 \mathrm{kDa}$ ). The concentrate was applied on a column of gel filtration Sephacryl S-200 equilibrated with buffer B. Proteins elution was performed with buffer $B$ at a flow rate of $30 \mathrm{ml} / \mathrm{h}$. rTPL was eluted between 1.3 and 1.5 void volumes (Figure 4A).

\section{Anion exchange chromatography Q-Sepharose FF}

Active fractions eluted from Sephacryl S200 were pooled, concentrated then applied to FPLC equipped with a Q-Sepharose FF column equilibrated with buffer $B$. The column was washed with the same buffer, then, proteins were eluted with a linear $\mathrm{NaCl}$ gradient from 25 to $350 \mathrm{mM}$ in buffer B. rTPL activity was eluted between 180 and $220 \mathrm{mM} \mathrm{NaCl}$ (Figure 4B).

\section{Filtration on Sephadex G100}

Active fractions were pooled, concentrated then loaded on a second gel filtration Sephadex G-100 equilibrated with buffer B. Elution of rTPL was performed with buffer $\mathrm{B}$ at a flow rate of $25 \mathrm{ml} / \mathrm{h}$. rTPL was eluted at 1.2 void volume (Figure 4C).

The fractions containing the rTPL activity were pooled and analyzed on SDS-PAGE.

A summary of the purification process is given in table 1. Starting with the whole P.pastoris culture supernatant, 13-fold purification was achieved and the overall recovery of enzyme activity was $32 \%$. The purification resulted in a significant increase in the specific activity from $399 \mathrm{U} / \mathrm{mg}$ to $5300 \mathrm{U} / \mathrm{mg}$.

From $500 \mathrm{ml}$ of P.pastoris cell culture media, about $2 \mathrm{mg}$ of pure rTPL was obtained with a specific activity of $5300 \mathrm{U} / \mathrm{mg}$ using gum arabic emulsified olive oil as substrate in the presence of colipase and $4 \mathrm{mM} \mathrm{NaDC}$ at $\mathrm{pH} 8.5$ and $37^{\circ} \mathrm{C}$.

\section{SDS-PAGE}

The fractions containing rTPL activity were pooled and analyzed on SDS-PAGE (Figure 4D). This figure shows that a single band with an apparent molecular weight of $50 \mathrm{kDa}$ was revealed for the recombinant TPL.

\section{$\mathrm{N}$-terminal Sequencing}

The N-terminal aminoacide sequence of recombinant TPL revealed 11 residues EAEAEFSEVCY (Figure 5A). This sequence shows the correct cleavage of the $\alpha$-factor signal sequence at the Kex2 cleavage site. Compared with the native lipase, the $\mathrm{N}$-terminal sequence of the recombinant lipase bears six amino acid residues derived from the EcoRI site ( $\mathrm{E}$ and $\mathrm{F}$ residues) and residues separating the Kex2 cleavage site and the EcoRI site (E,A,E, and A residues) in the pGAPZ $\alpha$ A vector (Figure $5 \mathrm{~B}$ ).

It is worth noticing that despite the presence an extra peptide of 6 amino acids on its $\mathrm{N}$-terminal part, the rTPL seems to share the same biochemical and kinetic properties with the native enzyme under the same experimental conditions ( $\mathrm{pH}$ stat technique). It will be interesting to compare the interfacial properties of both enzymes using a more sensitive method as the monomolecular film technique.

\section{Effect of temperature and $\mathrm{pH}$ on the activity and the stability of the rTPL}

In order to check if the optimal $\mathrm{pH}$ and temperature of lipase activity of TPL was affected compared to native one, we measured at different $\mathrm{pH}$ and different temperatures the TPL activity (Figure 6A and 6B). The results show that both rTPL and nTPL present an optimum activity at $37^{\circ} \mathrm{C}$ and $\mathrm{pH} 8.5$ (Figure $6 \mathrm{~A}-6 \mathrm{~B}$ ). At $55^{\circ} \mathrm{C}$, the rTPL and the nTPL keep $75 \%$ and $85 \%$ of their activity respectively. Up to $55^{\circ} \mathrm{C}$, the two enzymes retain only $10 \%$ of their activities.

To study the thermal stability of the rTPL and the nTPL, each enzyme was incubated at various temperatures for $30 \mathrm{~min}$ at $\mathrm{pH} 8$. The results show that both recombinant and native enzymes exhibit similar thermal stability behaviour. In fact, the two enzymes retain $80 \%$ and $95 \%$ of their activity, respectively, after $30 \mathrm{~min}$ of incubation at $50^{\circ} \mathrm{C}$. At temperature over $55^{\circ} \mathrm{C}$, the activity decreased dramatically to reach 15 to $20 \%$ for both enzymes at $60^{\circ} \mathrm{C}$ (Figure 6C).

For the enzyme stability at different $\mathrm{pH}$, the measurement of residual activity shows that both enzymes are stable in a wide $\mathrm{pH}$ range. Indeed, the rTPL and native TPL keep 100\% of their activity after 30 min incubation at $\mathrm{pH} 8$ and 9 . When incubated at $\mathrm{pH} 3$, both enzymes retained $70 \%$ of their activities (Figure 6D).

\section{Effect of bile salts and calcium ions on the rTPL activity}

It is well established that bile salts are strong inhibitors of all pure pancreatic lipases independently of their origins [26-28]. 

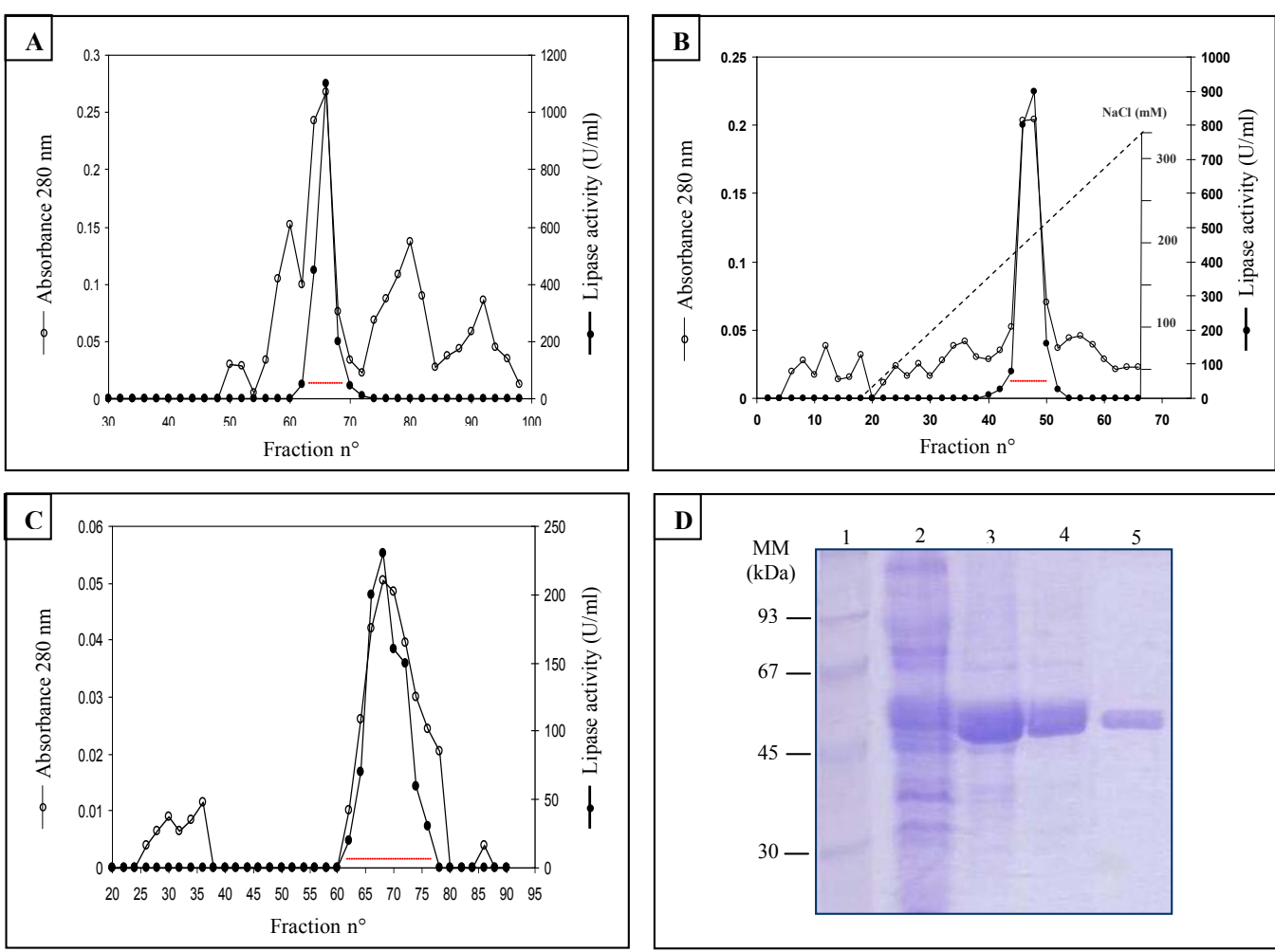

Figure 4 Purification steps of rTPL. (A) Chromatography of rTPL on Sephacryl S200; the column $(2.5 \times 150 \mathrm{~cm})$ was equilibrated with $25 \mathrm{mM}$ Tris buffer, pH 8.2, containing $25 \mathrm{mM} \mathrm{NaCl}$ and $2 \mathrm{mM}$ Benzamidine (buffer B). The elution of proteins was performed with the same buffer at a rate of $30 \mathrm{ml} / \mathrm{h}$. (B) Chromatography of rTPL on FPLC Mono-Q Sepharose. The column was equilibrated with buffer B; a linear gradient was applied from 25 to $350 \mathrm{mM} \mathrm{NaCl}$ in buffer B; the flow rate used was $2 \mathrm{ml} / \mathrm{min}$. (C) Chromatography of rTPL on Sephadex G100; the column was equilibrated in buffer $B$ and the flow rate was $25 \mathrm{ml} / \mathrm{h}$. The pooled fractions containing the rTPL activity were indicated by a dashed line.

(D) SDS-PAGE analysis of rTPL performed on 12\% gel. Lane1: Low molecular weight marker; Lane 2: culture supernatant; Lane 3: active fraction from Sephacryl-S200; Lane 4: active fraction from Q-Sepharose FF; Lane 5: active fraction from Sephadex-G100.

The effect of varying concentrations of sodium deoxycholate $(\mathrm{NaDC})$ on the rTPL and nTPL activities shows that, contrary to classical pancreatic lipases, the two enzymes are partially inhibited by the $\mathrm{NaDC}$ and retains respectively 30 and $25 \%$ of their activities at $8 \mathrm{mM}$ $\mathrm{NaDC}$ (Figure 7A).

In order to investigate the calcium dependence of the rTPL and nTPL, we measured the hydrolysis rates of olive oil emulsion by the two enzymes in the presence of various $\mathrm{CaCl}_{2}$ concentrations. Our results showed that, unlike most classical pancreatic lipases [29], calcium is not

Table 1 Flow sheet of rTPL purification

\begin{tabular}{ccccc}
\hline Purification step & $\begin{array}{c}\text { Total activity } \\
(\mathbf{U})\end{array}$ & $\begin{array}{c}\text { Specific activity } \\
(\mathbf{U} / \mathbf{m g})\end{array}$ & $\begin{array}{c}\text { Yield } \\
(\%)\end{array}$ & Fold \\
\hline Supernatant & 34380 & 399 & 100 & 1 \\
$\left(\mathrm{NH}_{4}\right)_{2} \mathrm{SO}_{4}$ Precipitation & 30800 & 1294 & 89.6 & 3.24 \\
DEAE-Cellulose & 24650 & 1454 & 71.7 & 3.64 \\
Sephacryl S-200 & 23540 & 3789 & 68.5 & 9.49 \\
Q-Sepharose FF & 14790 & 4150 & 43 & 10.4 \\
Sephadex G-100 & 11000 & 5300 & 32 & 13.28 \\
\hline
\end{tabular}

necessary to trigger rTPL and nTPL activities (Figure 7B) and, in the absence of $\mathrm{CaCl}_{2}$, the rTPL and nTPL retained about $10 \%$ of their activities. The maximal TPL activity was measured at $0.5 \mathrm{mM} \mathrm{CaCl}_{2}$.

\section{Conclusion}

In this study we reported the cloning of TPL gene into P.pastoris and the expression of the enzyme as a

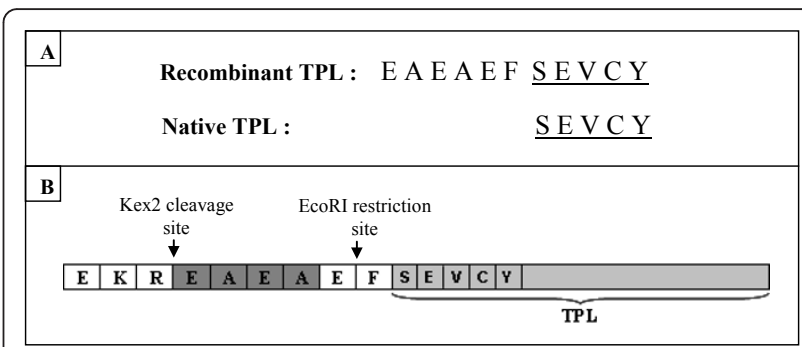

Figure 5 Recombinant TPL N-terminal sequence.(A) Alignment of native and recombinant TPL N-terminal sequences. (B) Amino acid sequences around the junction of signal peptide ( $\alpha$-factor) and mature TPL. 

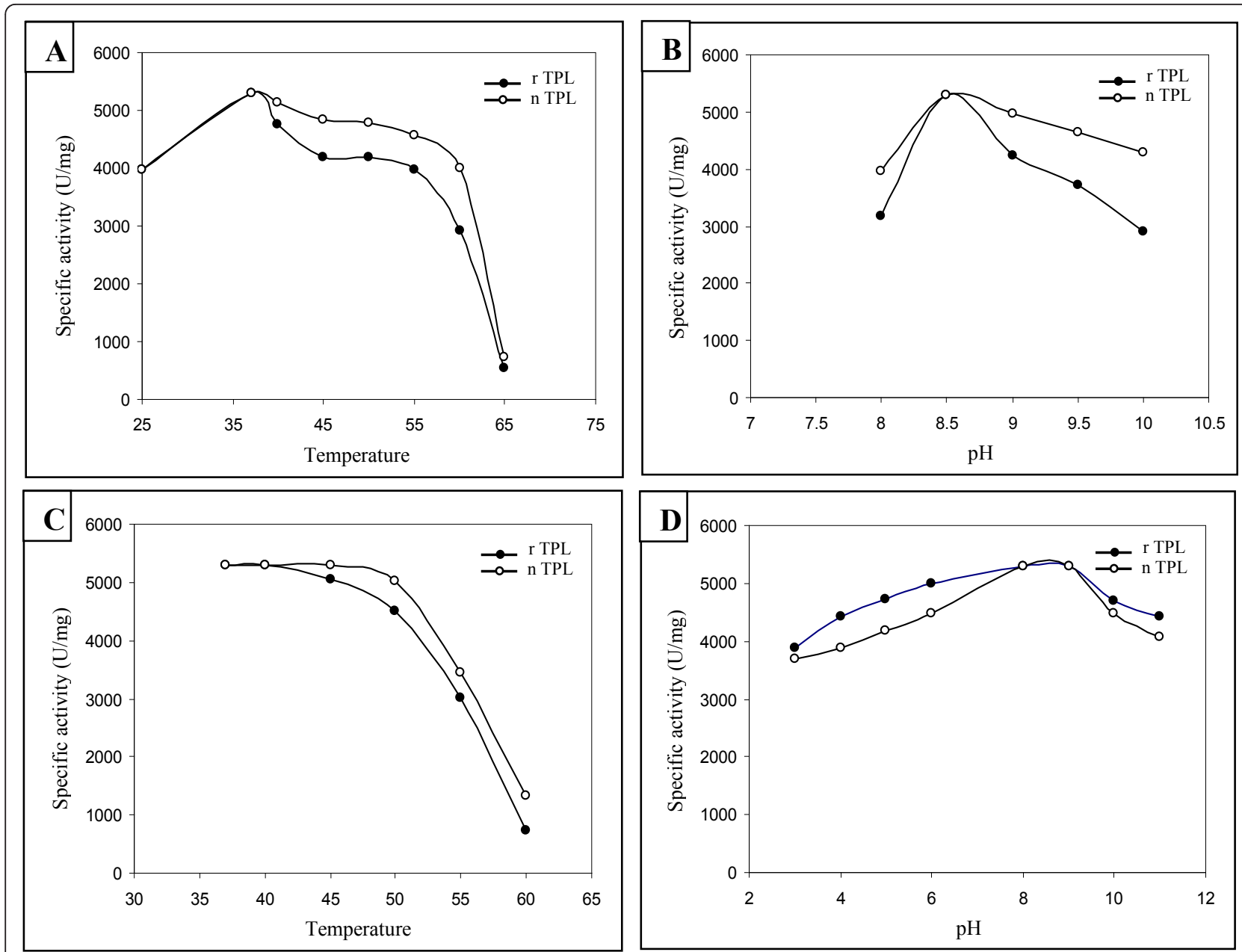

Figure 6 Effects of temperature and pH on rTPL activity and stability. (A) Effect of temperature on rTPL and nTPL activities. (B) Effect of pH on rTPL and native TPL activities. (C) Effect of temperature on rTPL and nTPL stability. The enzymes are incubated at different temperatures for 30 min. (D) Effect of pH on rTPL and nTPL stability. The enzymes are incubated at different pH for 30 min. Lipase activity was performed under standard conditions.

functional form. The expression level of the rTPL reached about $15 \mathrm{mg} / \mathrm{l}$ of culture medium after 4 days fermentation. The purified rTPL has a molecular mass of $50 \mathrm{kDa}$ and a specific activity of $5300 \mathrm{U} / \mathrm{mg}$ on emulsified olive oil and $9500 \mathrm{U} / \mathrm{mg}$ on tributyrin substrate. Some previous studies showed that the heterologous expression could lead to a modification of same biochemical properties [30]. In our case, the biochemical characterization of the rTPL and its comparison to the native TPL shows that the RTPL seams to be identical to the native enzyme which makes P.pastoris a promising system for the expression of TPL and its eventual mutants. This statement is suitable for using rTPL instead of nTPL to study the structure-function relationships of this interesting enzyme.

\section{Materials and methods}

\section{Yeast culture media}

Pichia pastoris liquid cell cultures were grown in YPD medium containing $10 \mathrm{~g}$ yeast extract, 20 Bacto-peptone and $20 \mathrm{~g}$ D-glucose. The YPDS medium was YPD medium to which $18.2 \mathrm{~g}$ sorbitol per liter was added. To prepare plates for solid cell cultures, $2 \%$ agar $(\mathrm{w} / \mathrm{v})$ was added to the YPD medium.

\section{Strains, plasmid and reagents}

The P.pastoris host strain was X33 (wild-type strain from Invitrogen). The P.pastoris transfer vector pGAP$\mathrm{Z} \alpha \mathrm{A}$ (Invitrogen) used for yeast transformation contained the selectable marker Zeocin, which is bifunctional in both Pichia and Escherchia coli, the 

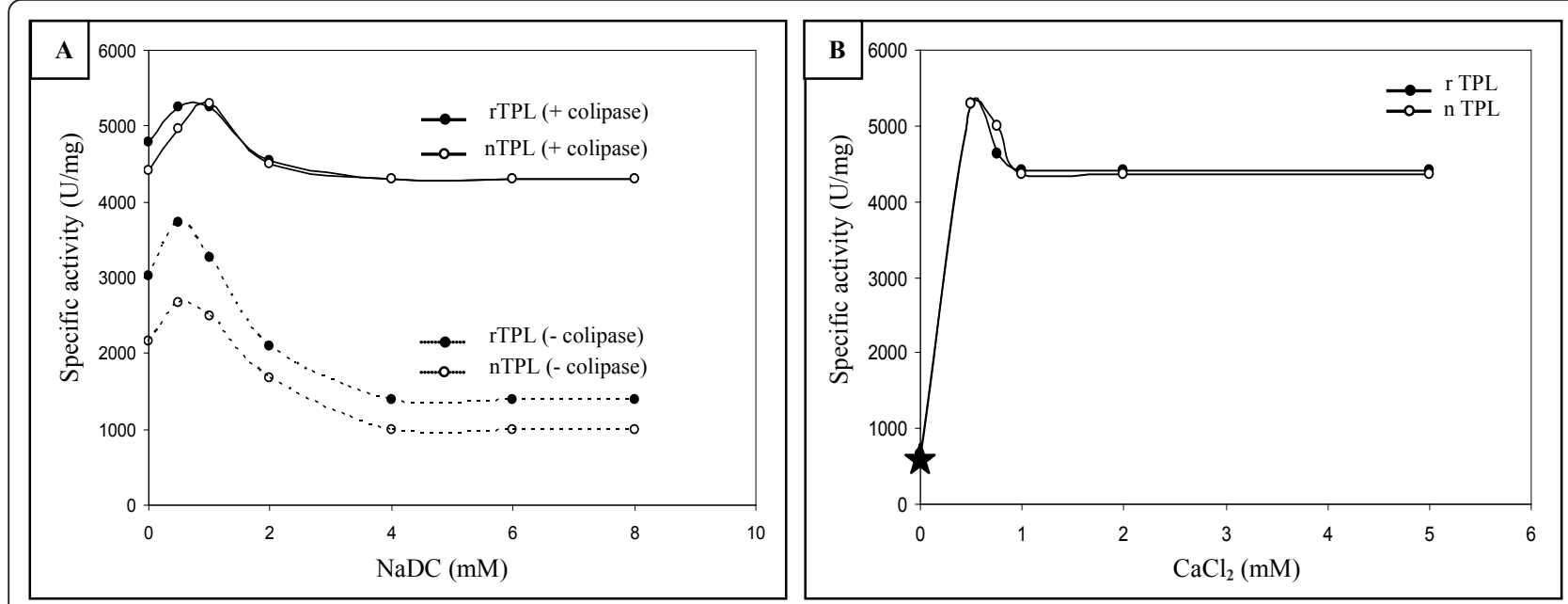

Figure 7 Effect of increasing concentrations of bile salt $(\mathrm{NaDC})$ and calcium ions $(\mathrm{Ca2+})$ on the rate of hydrolysis of olive oil emulsion by the rTPL. (A) Effect of increasing concentration of bile salt ( $\mathrm{NaDC}$ ) on the rate of hydrolysis of olive oil emulsion by the rTPL and the nTPL. Lipolytic activity was measured at $\mathrm{pH} 8.5$ and $37^{\circ} \mathrm{C}$ in the absence or in the presence of a molar excess of colipase. (B) Effect of increasing concentration of calcium ions $\left(\mathrm{Ca}^{2+}\right)$ on the rate of hydrolysis of olive oil emulsion by the rTPL and the nTPL. Lipolytic activity was measured at $\mathrm{pH} 8.5$ and $37^{\circ} \mathrm{C}$. The star indicates the lipase activity measured in the absence of $\mathrm{CaCl} 2$ and in the presence of $10 \mathrm{mM}$ EDTA.

5'GAP promoter and the 3' AOX TT transcription termination sequences. The Pfx DNA polymerase, T4 DNA ligase, PCR purification kit and Midi-Prep Kit were purchased from Promega.

\section{Construction of TPL expression vector}

The cDNA sequence encoding the TPL was previously isolated and cloned into the pGEM-T Easy vector in our laboratory by Fendri et al (2006).

Using the TPL cDNA as template, a DNA fragment of $1353 \mathrm{pb}$ was amplified by PCR with sens (5'-GATCGAATTCTCTGAAGTTTGCTATGAC-3') and antisense (5'-GATCGAATTCTTAGCAAGCAGTAAG GGT-3') primers introducing EcoRI sites (underlined) immediately upstream of the first codon (TCT) and downstream of the stop codon.

The PCR product was then cloned into the PCRBlunt-Topo vector using the PCR-Blunt-Topo cloning kit according to the manufactures's protocol (Invitrogen). Protoplasts of E.coli DH5 $\alpha$ were transformed with the ligation mixture. The presence of the expected insert in the resulting plasmids was determined by restriction analysis.

The resulting recombinant vector PCR-Blunt-TopoTPL was digested with the restriction enzyme EcoRI. The EcoRI-digested insert was purified and inserted into pGAPZ $\alpha$ A P.pastoris transfert vector downstream of the GAP constitutive promoter as described by Sias [31].

The consequent plasmid (pGAPZ $\alpha$ A-TPL, 4512pb) was transformed into E. coli DH5 $\alpha$ by the chemical method [32] and the transformed clones were selected on LuriaBertani (LB) plates containing $25 \mu \mathrm{g} / \mathrm{ml}$ Zeocin.
The recombinant plasmids were then insolated using the Midi-prep purification system. The gene coding for TPL with the $\alpha$-factor was sequenced, proving that no mutation occurred during the PCR. Experiments were performed 3 times with different clones.

\section{Transformation of P.pastoris and screening of TPL transformants}

Electrocompetent X33 cells, prepared using standard methods [33], was transformed with $10 \mu \mathrm{g}$ of BspHIlinearized pGAPZ $\alpha$ A-TPL by electroporation according to Invitrogen manual. The recombinant yeast clones were selected on YPDS plates containing $100 \mu \mathrm{g} / \mathrm{ml}$ Zeocin.

The colonies were subsequently screened by PCR using as template the genomic DNA extracted from different transformants and the pGAPZ $\alpha$ A universal primers (pGAP Forward and AOX1 primers) to confirm the integration of the TPL DNA into the yeast genome.

Positive transformants were grown in $250 \mathrm{ml}$ Erlenmeyer flasks containing $50 \mathrm{ml}$ YPD medium with 100 $\mu \mathrm{g} / \mathrm{ml}$ Zeocin, at $30^{\circ} \mathrm{C}$ under shaking at $150 \mathrm{rpm}$. The time-course of rTPL secretion into the culture medium was determined using various clones.

\section{Real-time PCR}

The ICycler (Biorad) was used for Q-PCR amplification and detection. Q-PCR was prepared in $25 \mu \mathrm{l}$ reaction mixture. Each reaction well contains $5 \mu \mathrm{l}$ of template DNA (100 ng), $12.5 \mu \mathrm{l}$ of SensiMix dT, $0.5 \mu \mathrm{l}$ of SYBR Green I solution, $4 \mathrm{mM} \mathrm{MgCl} 2$ and $10 \mathrm{mM}$ of forward (5'-GCAATAGGACATCTTGACTTT-3') and reverse (5'-ATCTGCATAGTGACCCATGTT-3') primers to 
generate an amplicon of $276 \mathrm{pb}$. Serial 10-fold dilutions of plasmid DNA (pGAPZaA/TPL) were conduced to establish the standard curve. The negative control (without DNA template) was included in experimental runs. The Q-PCR cycling program was $10 \mathrm{~min}$ at $95^{\circ} \mathrm{C}$ for activation of the hot-start enzyme, followed by 40 cycles of denaturation at $95^{\circ} \mathrm{C}$ for $15 \mathrm{~s}$, annealing at $52^{\circ} \mathrm{C}$ for $30 \mathrm{~s}$ and elongation at $72^{\circ} \mathrm{C}$ for $30 \mathrm{~s}$. Melting curves analysis was performed after completed Q-PCR collecting fluorescence between 60 and $95^{\circ} \mathrm{C}$ at $1{ }^{\circ} \mathrm{C}$ increments.

\section{Production and purification of rTPL in P.pastoris}

The clone showing the most important activity level was selected to produce the recombinant protein. It was then pre-grown at $30^{\circ}$ in $250 \mathrm{ml}$ shake flasks containing $50 \mathrm{ml}$ YPD medium for $24 \mathrm{~h}$ to an $\mathrm{OD}_{600}$ of 6 . This cell culture was further used to inoculate five $500 \mathrm{ml}$ shake flasks containing $100 \mathrm{ml}$ YPD medium without Zeocin.

The culture was started at an optical density of 1 to establish reproducible cells culture conditions. The production of rTPL was conducted at $30^{\circ} \mathrm{C}$ for 4 days with shaking at $150 \mathrm{rpm}$.

Five hundred milliliters of culture medium were collected after fermentation and used to purify the recombinant enzyme by performing a five-step purification protocol comprising the following steps: an ammonium sulfate precipitation; anion exchange chromatography on DEAE-Cellulose; filtration on Sephacryl S200; anion exchange chromatography on Q-Sepharose FF and a filtration on Sephadex G100. Native TPL was purified according to the protocol established by Sayari et al [8].

\section{SDS-PAGE}

Sodium dodecyl sulfate polyacrylamide gel electrophpresis (SDS-PAGE) was performed with a $12 \%$ polyacrylamide gel as described by Laemmli [34]. After electrophoresis, proteins were strained with coomassie brilliant blue R-250.

\section{Amino acid sequensing}

The N-Terminal sequence of the recombinant enzyme were determined by automated Edman degradation, using an Applied Biosytems Procise 492 protein sequencer equipped with the $140 \mathrm{C}$ HPLC system [35].

\section{Lipase activity determination}

The lipase activity was measured titrimetically at $\mathrm{pH} 8.5$ and $37^{\circ} \mathrm{C}$ with a pH-Stat using tributyrin $(0.25 \mathrm{ml})$ in 30 $\mathrm{ml}$ of $2 \mathrm{mM}$ Tris- $\mathrm{HCl}, \mathrm{pH} 8.5150 \mathrm{mM} \mathrm{NaCl}$ or olive oil emulsion in presence of $4 \mathrm{mM} \mathrm{NaDC}$ and Turkey colipase [36]. One lipase unit corresponds to $1 \mu \mathrm{mol}$ of fatty acid liberated per min.

\section{Determination of protein concentration}

Protein concentration was determined as described by Bradford [37] using BSA $\left(\mathrm{E}_{1 \mathrm{~cm}}^{1 \%}=6.7\right)$ as reference.

\section{Effect of temperature and $\mathrm{pH}$ on enzyme stability and activity}

Optimal $\mathrm{pH}$ and temperature were determined examining the lipase activity at different temperature and $\mathrm{pH}$ by $\mathrm{pH}$-Stat assay using olive oil as substrate. $\mathrm{pH}$ stability was determined by incubating lipase solution for $30 \mathrm{~min}$ at different $\mathrm{pH}$ at $4^{\circ} \mathrm{C}$. Thermostability was determined by pre-incubating the enzyme at temperatures ranging from $37^{\circ}$ to $60^{\circ} \mathrm{C}$. The lipase activity was measured after centrifugation under standard conditions.

Effect of bile salts and calcium ions on the enzyme activity In order to study the bile salt effect on the rTPL and nTPL activities, lipase activity was measured using emulsified olive oil as substrate at $37^{\circ} \mathrm{C}$ and $\mathrm{pH} 8.5$ in the presence of increasing concentration of sodium deoxycholate $(\mathrm{NaDC})$ in both the presence and the absence of an excess of colipase.

To study the calcium dependence of the two enzymes, lipase activity was measured using emulsified olive oil as substrate at $37^{\circ} \mathrm{C}$ and $\mathrm{pH} 8.5$ in the presence of an excess of colipase, $4 \mathrm{mM} \mathrm{NaDC}$ and an increasing concentrations of $\mathrm{CaCl}_{2}$.

\section{Acknowledgements}

This work received financial support from "Ministère de l'enseignement supérieur et de la recherche scientifique" granted to the "Laboratoire de Biochimie et de Génie Enzymatique des Lipases".

\section{Authors' contributions}

MBA and YBA carried out the studies, analyzed the data and drafted the manuscript. AK helped technically and with the analysis of the data. AF participated in the study design and helped to draft the manuscript. YG helped with the discussion of the data and the correction of the manuscript. All authors have read and approved the final manuscript.

\section{Competing interests}

The authors declare that they have no competing interests.

Received: 31 December 2010 Accepted: 27 January 2011 Published: 27 January 2011

\section{References}

1. Schmid RD, Verger $R$, Lipases : interfacial enzymes with attractive applications. Angewandte Chem. Int. Ed 1998, 37:1608-1633.

2. Winkler FK, D'arcy A, Hunziker W: Structure of human pancreatic lipase. Nature 1990, 343:771-774.

3. Van Tilbeurgh H, Egloff MP, Martinez C, Rugani N, Verger R, Cambillau C: Interfacial activation of the lipase-procolipase complex by mixed micelles revealed by X-ray crystallography. Nature 1993, 362:814-820.

4. Ollis DL, Cheah E, Cygler M, Dijkstra B, Frolow F, Franken SM, Harel M, Remington SJ, Silman I, Schrag J: The a/ $\beta$ hydrolase fold. Prot. Eng 1992, 5:197-211

5. Van Tilbeurgh H, Sarda L, Verger L, Cambillau C: Structure of the pancreatic lipase-procolipase complex. Nature 1992, 359:159-162. 
6. Withers-Martinez C, Carrière F, Verger R, Bourgeois D, Cambillau C: A pancreatic lipase with a phospholipase A1 activity: crystal structure of a chimeric pancreatic lipase-related protein 2 from guinea pig. Structure 1996, 4:1363-1374.

7. Fendri A, Frikha F, Miled N, Gargouri Y: Cloning and molecular modelling of turkey pancreatic lipase: structural explanation of the increased interaction power with lipidic interface. Biochimie 2006, 88:1401-1407.

8. Sayari A, Mejdoub H, Gargouri Y: Characterization of turkey pancreatic lipase. Biochimie 2000, 82:153-159.

9. Fendri A, Sayari A, Gargouri Y: Kinetic properties of turkey pancreatic lipase: a comparative study with emulsified tributyrin and monomolecular dicaprin. Chirality 2005, 17:57-62.

10. Gargouri Y, Pieroni G, Lowe PA, Sarda L, Verger R: Human gastric lipase. The effect of amphiphiles. Eur. J. Biochem 1986, 156:305-310.

11. Gargouri Y, Bensalah A, Douchet I, Verger R: Kinetic behaviour of five pancreatic lipases using emulsion and monomolecular films of synthetic glycerides. Biochem. Biophys. Acta 1995, 1257:223-229.

12. Ben Bacha A, Fendri A, Gargouri Y, Mejdoub H, Miled N: Proteolytic cleavage of ostrich and turkey pancreatic lipases: production of an active N-terminal domain. Pancreas 2007, 35:55-61.

13. Bousset-Risso M, Bonicel J, Rovery M: Limited proteolysis of porcine pancreatic lipase: Lability of the Phe 335-Ala 336 bond towards chymotrypsin. FEBS lett 1985, 182:323-326.

14. Abousalham A, Chaillan C, Kerfelee B: Uncoupling of catalysis and colipase binding in pancreatic lipase by limited proteolysis. Prot. Eng 1992, 5:105-111.

15. Gellissen G: Heterologous protein production in methylotrophic yeasts. Appl. Microbiol. Biotechnol 2000, 54:741-750.

16. Cereghino JL, Cregg JM: Heterologous protein expression in the methylotrophic yeast Pichia pastoris. FEMS Microbiol. Rev 2000, 24:45-66.

17. Waterham HR, Digan ME, Koutz PJ, Lair SV, Cregg JM: Isolation of the Pichia pastoris glyceraldehyde-3-phosphate dehydrogenase gene and regulation and use of its promoter. Gene 1997, 186:37-44.

18. Mattanovich D, Gasser B, Hohenblum H, Sauer M: Stress in recombinant protein producing yeasts. Journal of Biotechnology 2004, 113:121-135.

19. Sato R, Matsumoto T, Hidaka N, Imai Y, Abe K, Takahashi S, Yamada R, Kera Y: Cloning and expression of carp acetylcholinesterase gene in Pichia pastoris and characterization of the recombinant enzyme. Protein Expression and Purification 2009, 64:205-212.

20. Sebban-Kreuzer C, Deprez-Beauclair P, Berton A, Crenon I: High-level expression of nonglycosylated human pancreatic lipase-related protein 2 in Pichia pastoris. Protein Expression and Purification 2006, 49:284-291.

21. Aloulou A, Grandval P, De Caro J, De Caro A, Carrière F: Constitutive expression of human pancreatic lipase-related protein 1 in Pichia pastoris. Protein Expression and Purification 2006, 47:415-421.

22. Murasugi1 A, Asami Y, Mera-Kikuchi Y: Production of Recombinant Human Bile Salt-Stimulated Lipase in Pichia pastoris. Protein Expression and Purification 2001, 23:282-288.

23. Yu M, Lange S, Richter S, Tan T, Schmid RD: High-level expression of extracellular lipase Lip2 from Yarrowia lipolytica in Pichia pastoris and its purification and characterization. Protein Expression and Purification 2007, 53:255-263.

24. Tang SJ, Shaw JF, Sun KH, Sun GH, Chang TY, Lin CK, Lo YC, Lee GC: Recombinant expression and characterization of the Candida rugosa lip4 lipase in Pichia pastoris: comparison of glycosylation, activity, and stability. Arch. Biochem. Biophys 2001, 387:93-98.

25. Richter S, Nieveler J, Schulze H, Bachmann TT, Schmid RD: High yield production of a mutant Nippostrongylus brasiliensis Acetylcholinesterase in Pichia pastoris and its purification. Biotechnol. Bioeng 2005, 93:1017-1022

26. Gargouri $Y$, Julien R, Bois AG, Verger R, Sarda L: Studies on the detergent inhibition of pancreatic lipase activity. J. Lipid. Res 1983, 24:1336-1342.

27. Gargouri Y, Pièroni G, Lowe PA, Sarda L, Verger R: Human gastric lipase: the effect of amphiphiles. Eur. J. Biochem 1985, 156:305-310.

28. Ben Bacha A, Gargouri Y, Ben Ali Y, Miled N, Reinbolt J, Mejdoub H: Purification and biochemical characterization of ostrich pancreatic lipase. Enzyme and Microbial Technology 2005, 37:309-317.

29. Benzonana $\mathrm{G}$ : On the role of $\mathrm{Ca} 2+$ during the hydrolysis of insoluble triglycerides by pancreatic lipase in the presence of bile salts. Biochim. Biophys. Acta 1968, 151:137-146.
30. Horchani H, Sabrina L, Régine L, Sayari A, Gargouri Y, Verger R: Heterologous expression and $\mathrm{N}$-terminal His-tagging processes affect the catalytic properties of staphylococcal lipases: A monolayer study. Journal of Colloid and Interface Science 2010, 350:586-594.

31. Sias B, Ferrato F, Grandval P, Lafont D, Boullanger P, De Caro A, Leboeuf $B$, Verger RF: Carriere, Human pancreatic lipase-related protein 2 is a galactolipase. Biochemistry 2004, 43:10138-10148.

32. Sambrook J, Fritsch EF, Maniatis T: Molecular Cloning: A Laboratoty Manual. Cold Spring Harbor Laboratory Press, New York; 1989.

33. Cregg JM, Russell KA: Transformation. Methods Mol. Biol 1998, 103:27-39.

34. Laemmli UK: Cleavage of structural proteins during the assembly of the head of bacteriophage T4. Nature 1970, 227:680-685.

35. Hewick RM, Hunkapiller MW, Hood LE, Dreyer WJ: A gas-liquid solid phase peptide and protein sequenator. J.Biol. Chem 1981, 256:7990-7997.

36. Rathelot J, Julien R, Canioni P, Coeroli C, Sarda L: Studies on the effect of bile salt and colipase on enzymatic lipolysis. Improved method for the determination of pancreatic lipase and colipase. Biochimie 1975, 57:1117-1122.

37. Bradford MM: A rapid and sensitive method for the quantitation of protein utilizing the principle of protein-dye binding. Anal. Biochem 1976, 72:248-254.

doi:10.1186/1476-511X-10-24

Cite this article as: Bou Ali et al:: Purification and characterization of the first recombinant bird pancreatic lipase expressed in Pichia pastoris: The turkey. Lipids in Health and Disease 2011 10:24.

\section{Submit your next manuscript to BioMed Central and take full advantage of:}

- Convenient online submission

- Thorough peer review

- No space constraints or color figure charges

- Immediate publication on acceptance

- Inclusion in PubMed, CAS, Scopus and Google Scholar

- Research which is freely available for redistribution

Submit your manuscript at www.biomedcentral.com/submit
C) Biomed Central 